\title{
Bacillus subtilis A Potential Probiotic Bacterium to Formulate Functional Feeds for Aquaculture
}

\section{Jorge Olmos ${ }^{1 *}$ and $\mathrm{J}$ Paniagua-Michel ${ }^{2}$}

${ }^{1}$ Molecular Microbiology Laboratory, Department of Marine Biotechnology, Centro de Investigación Científica y de Educación Superior de Ensenada (CICESE), Ensenada, Baja California, México

${ }^{2}$ Bioactive Compounds and Bioremediation Laboratory, Department of Marine Biotechnology, Centro de Investigación Científica y de Educación Superior de Ensenada (CICESE), Ensenada, Baja California, México

\begin{abstract}
In shrimp/fish aquaculture, feed represents the most expensive production cost. The quantity and quality of diets are primary factors influencing shrimp/fish growth, health status, disease prevention, pound contamination and expenses. Utilization of probiotic bacteria has emerged as a solution with enormous applications in the aquaculture feeding industry. Bacillus species principally $B$. subtilis are one of the most investigated bacteria for animal probiotic development due to: a) versatility of growth nutrients utilization, b) high level of enzymes production, c) secretion of antimicrobial compounds, d) spore producers, e) develops in aerobic and anaerobic conditions, and f) $B$. subtilis is Generally Recognized As Safe (GRAS) by the Food and Drug Administration (FDA). Functional feeds development with alternative-economic nutrient vegetable sources of proteins, carbohydrates, lipids and Bacillus subtilis probiotic strains, must be considered in shrimp/fish aquaculture production systems; as an option to eliminate animal feed ingredients, improves digestion-assimilation, reduce water pollution and diseases, and to increase yields and profits.
\end{abstract}

Keywords: Bacillus subtilis; Probiotics; Functional Feed; Vegetable ingredients

\section{Bacillus subtilis Properties}

Bacteria of the Bacillus genus are among the most widespread microorganisms in nature, they can be found in soil, water and air. Bacillus constitutes a diverse group of rod-shaped, Gram-positive bacteria, characterized by their ability to produce a robust spore [1-5]. The Bacillus subtilis genome is totally sequenced, leading to generation of a great amount of basic knowledge in this bacterium [6]. Additionally, developments of molecular and genetic methodologies are well established in B. subtilis [7-9]. B. subtilis is not harmful to mammals, including humans, and is commercially important as producer of a high and diverse amount of secondary metabolites like antibiotics, fine chemicals and enzymes, as well as heterologous proteins, antigens and vaccines $[1,10-15]$. B. subtilis grow efficiently with low-cost carbon and nitrogen sources, because its enzymes are very efficient breaking down a great variety of proteins, carbohydrates and lipids from animal and vegetable origin, into their constituent units [1,16-18]. The enzymes also degrade organic accumulated debris from shrimp/fish cultures inducing ponds bioremediation and consequently the prevention of viral and bacterial diseases [19-22]. On the other hand, the antimicrobial activity of Bacillus is greatly determined by their ability to produce antibiotics, principally from peptide origin [23]. There were identified 795 antibiotics from Bacillus species [11]. B. subtilis is the genus most productive species devoting $4-5 \%$ of its genome to their synthesis, producing 66 antibiotics [11]. Furthermore, Bacillus subtilis is Generally Recognized as Safe (GRAS) by the FDA, meaning this bacterium is not harmful to animals or humans (Figure 1). Taking into account beneficial properties of B. subtilis, this bacterium is a potential probiotic candidate to be considered in "Functional Feeds" of crustaceans and fishes [16-19,24].

\section{Bacillus subtilis Probiotic Capacities}

B. subtilis is between the oldies species on earth, reason why animals and humans since the beginning of their existence have been in contact with this bacterium $[25,26]$. In this sense, recognition of $B$. subtilis for animal and human immune system is well established and a symbiotic relationship had been developed for a long period of time [27]. On the other hand, million years of evolution has created an amazing quorum sensing communication-recognition mechanism between beneficial and pathogenic bacteria $[1,28,29]$. However, animals and humans only sense pathogens when the disease had been developed, due equilibrium between beneficial and pathogenic bacteria had been broken because; environmental, nutritional and/or metabolic changes has occurred favoring pathogens proliferation. Synthetic antibiotics was the first option to control pathogens overgrowth in humans and animals, however the unregulated use of these compounds induced a multi-resistant mechanisms preferentially developed by the pathogenic bacteria [30]. Today, antibiotics utilization is well regulated in humans and also in animals including aquaculture. In this sense, the utilization of beneficial bacteria (probiotics) has emerge as an alternative due good results are been obtained in both; animals and humans [27].

The term "probiotics" was derived from the Greek word, meaning "for life" [31]. According to the currently adopted definition by FAO/ WHO, probiotics are: "Live microorganisms which when administered in adequate amounts confer a health benefit on the host [32]. Since 50 year ago exists a scientific and commercial interest in the use of beneficial bacteria for the prevention and treatment of diseases $[27,33]$. Lactobacillus and Bifidobacterium genera has been used almost exclusively for the competitive exclusion of pathogenic bacteria from the

*Corresponding author: Jorge Olmos, Molecular Microbiology Laboratory, Department of Marine Biotechnology, Centro de Investigación Científica y de Educación Superior de Ensenada (CICESE), Ensenada, Baja California, México, Tel: + 52-6461750500; Fax: 52-6461750534; E-mail: jolmos@cicese.mx

Received September 15, 2014; Accepted October 15, 2014; Published October 22, 2014

Citation: Olmos J, Paniagua-Michel J (2014) Bacillus subtilis A Potential Probiotic Bacterium to Formulate Functional Feeds for Aquaculture. J Microb Biochem Technol 6: 361-365. doi:10.4172/1948-5948.1000169

Copyright: ( 2014 Olmos J, et al. This is an open-access article distributed under the terms of the Creative Commons Attribution License, which permits unrestricted use, distribution, and reproduction in any medium, provided the original author and source are credited 


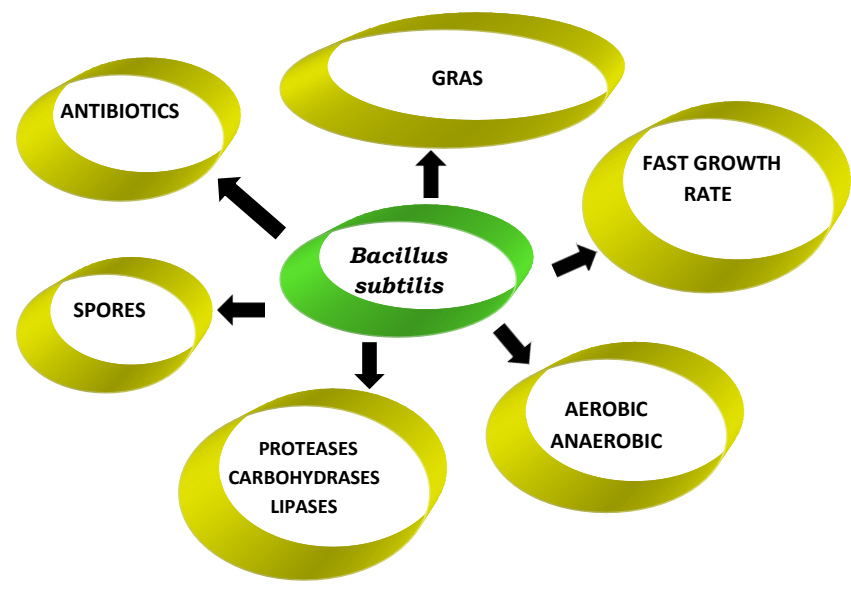

Figure 1: Bacillus subtilis intrinsic properties.

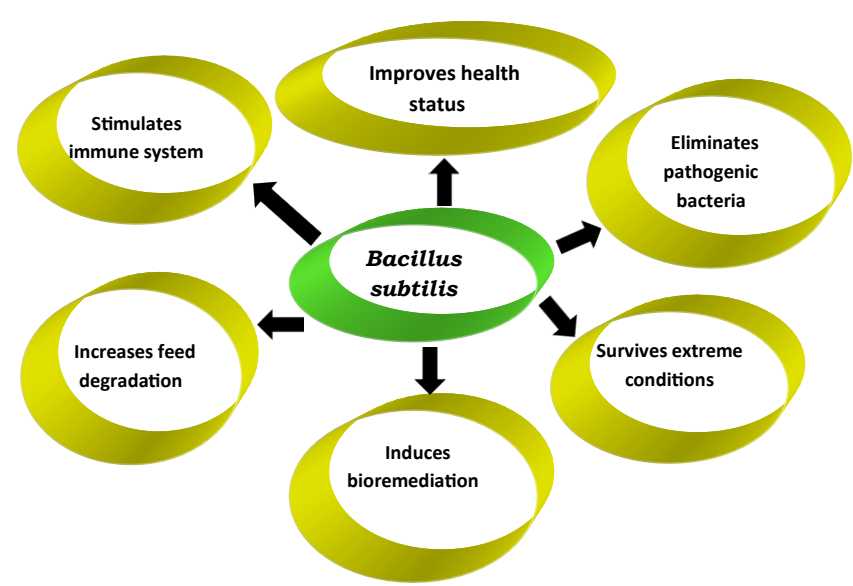

Figure 2: Bacillus subtilis probiotic capacities in humans and animals.

gut of humans, farmed animals and most recently aquaculture species $[23,27,33,34]$. However, the utilization of probiotic to application others than pathogenic bacterial exclusion are now been develop in several areas like; immune system stimulation, vaccine production, bioremediation and functional feed development [15-19,24,35]. In this sense, and based in our own experiences, we redefined probiotics as a living microbial supplement that: (a) positively affects host health status by modifying the host-associated microbial community and its immune system; (b) secrete a variety of enzymes to increases feed degradation-assimilation enhancing its nutritional values; (c) improves quality of environmental parameters by the bioremediation of waste products and (d) support extreme changing environmental and physical parameters (Figure 2).

However, to accomplish all these objectives the utilization of "Bacillus subtilis spore producing multifunctional probiotic bacterium" it is recommended, to support environmental, nutritional and metabolic changing conditions where probiotic will be involve and most importantly, to take advantage of them [17-19,24,35-37]. In this sense, $B$. subtilis spores have the capacity to resist extreme $\mathrm{pH}$ conditions, UV irradiation, high temperatures, solvents and long time periods of storage without refrigeration [1] In summary, B. subtilis has a) versatility of growth nutrients utilization, b) high level of enzymes production, c) secretion of antimicrobial compounds, d) spore producer, e) develops in aerobic and anaerobic conditions, and f) $B$. subtilis is Generally Recognized As Safe (GRAS) by the Food and Drug Administration (FDA) (Figure 1). In this sense, B. subtilis in "theory" could be considered as a perfect multifunctional probiotic bacterium for humans and animals [1,16-19,23,24,27,33,38,39].

\section{Bacillus subtilis Recombinant Probiotic Development}

The global sales of probiotic supplements were predicted to rise $48 \%$ from $\$ 2.7$ bn in 2011 to $\$ 4$ bn in 2016. In US, per capita spending on probiotic supplements is expected to nearly double by 2016 and overtakes Japan [34]. In this sense, the utilization of non-recombinant probiotic strains in humans, farmed animals and aquaculture systems is well established, principally for the competitive exclusion of pathogenic bacteria (Table 1) [27,33,40-42].

On the other hand, utilization of recombinant probiotic strains in humans and animals it is not accepted due Genetically Modified Organism (GMO) regulations [27,43]. B. subtilis strains with overproduction of antimicrobial peptides or enzymes already exist scientifically and commercially, but only their products are being sold not the strains $[12,23,44,45]$. Overproduction of antimicrobial peptides and/or enzymes by recombinant probiotic strains could induce health problems in animals and consequently in the consumers, as the unregulated utilization of synthetic antibiotics did. Human and animal market "supposedly" consumes non recombinant Bacillus probiotic strains, due health FDA regulation and restrictions that must be solved, before acceptance of GMO products commercialization.

However, diseases like the one induced by White Spot Syndrome Virus (WSSV) in shrimps, cannot be controlled at the moment by any non-recombinant bacterial probiotic strain. In this sense, production of vaccines using $B$. subtilis probiotic recombinant strains, are starting to be develops to prevent disease impacts on animals and humans $[15,46$ 48]. Environmental contamination and utilization of strong stressful agents are inducing development of new bacterial and virus diseases. In this sense, recombinant probiotic utilization could be the only effective way to fight versus pathogen agent's proliferation. However, even when promising results have been obtained inducing immunization with recombinant $B$. subtilis probiotic strains, several FDA tests must be carried out in animal models before a massive food/feed inclusion and commercialization of recombinant probiotics can be done.

\section{Aquaculture Development Restrictions}

The United Nations Food and Agriculture Organization (FAO) define aquaculture as the farming of aquatic organisms including mollusks, crustaceans, fish and plants. Marine capture fisheries and aquaculture, supplied the world with about 154 million tons of marine products in 2011 [49]. However, global population demanding for marine food products is increasing around the world, but fisheries capture production has leveled off, due principal fishing areas have reached their maximum potential and some have started to go down $[24,49,50]$. In this sense, aquaculture the multibillion dollar fastest growing industry of the world food economy, is increasing by more than $10 \%$ per year and currently accounts for more than $50 \%$ of all shrimp/ fish consumed [49]. For this reason, prices of fishmeal and oil utilized precisely to produce aquaculture feeds have increased considerably last years, making the industry unprofitable in many countries [24,50]. Worry about negative impacts of fishmeal and oil overproduction in ecology of global fisheries and environmental alterations have arisen $[51,52]$. Aquaculture represents the greatest potential to meet demands for aquatic food products; however, instead of helping to ease the crisis 


\begin{tabular}{|c|c|c|c|}
\hline \multicolumn{4}{|c|}{ BACILLUS PROBIOTIC FOR HUMAN USE } \\
\hline Product & \multicolumn{2}{|c|}{ Manufacturer } & Comments \\
\hline Bio-Kult ${ }^{\circledR}$ & \multicolumn{2}{|c|}{ Probiotics International Ltd (Protexin), UK. http://www.bio-kult.com } & $\begin{array}{l}\text { B. subtilis is one component of } 14 \text { strains carried in this probiotic supplement } \\
\text { (minimum } 2 \times 10^{9} \mathrm{CFU} / \text { capsule). }\end{array}$ \\
\hline Medilac-Vita ${ }^{\circledR}$ & \multicolumn{2}{|c|}{$\begin{array}{l}\text { Hanmi Pharmaceutical Co. Ltd., Seoul, Korea http://www. } \\
\text { hanmipharm.com }\end{array}$} & B. subtilis in combination with Streptococcus faecium (at 108/g). \\
\hline $\begin{array}{l}\text { Primal } \\
\text { Defense }^{\circledast}\end{array}$ & \multicolumn{2}{|c|}{ Garden of Life $^{\circledR}$, Florida, USA. http://www.gardenoflife.com } & B. subtilis is one of the 12 bacteria species in this probiotic. \\
\hline Biobaby $^{\circledR}$ & \multicolumn{2}{|c|}{$\begin{array}{l}\text { Ildong Pharmaceutical Ho Chi Minh, Vietnam http://www.thuocbo. } \\
\text { com.vn/Danh-muc-thuoc-bo/men-vi-sinh/biobaby.html }\end{array}$} & $\begin{array}{l}\text { Granules for solution with } B \text {. subtilis } 3 \mathrm{mg} / \mathrm{g}\left(3 \times 10^{6} \mathrm{CFU} / \mathrm{g}\right) \text {, in combination with } \\
\text { Lactobacillus sporogenes and Clostridium butyricum }\left(1 \times 10^{7} \mathrm{CFU} / \mathrm{g}\right) \text {. }\end{array}$ \\
\hline Totalflora & \multicolumn{2}{|c|}{$\begin{array}{l}\text { Roux-Ocefa Laboratorios Buenos Aires, Argentina http://www.roux- } \\
\text { ocefa.com }\end{array}$} & $\begin{array}{l}\text { Each capsule contains: Lactobacillus acidophilus, Bifidobacterium bifidum, } \\
\text { Bacillus subtilis, Saccharomyces cerevisiae and Bacteriophages. }\end{array}$ \\
\hline \multicolumn{4}{|c|}{ BACILLUS PROBIOTIC FOR AQUACULTURE } \\
\hline Brand & \multicolumn{2}{|c|}{ Manufacturer } & Comments \\
\hline \begin{tabular}{|l|} 
Naturalle \\
Bacillus subtilis
\end{tabular} & \multicolumn{2}{|c|}{$\begin{array}{l}\text { Wuhan Nature's Favour Bioengineering Co., Ltd, Wuhan City, China } \\
\text { http://www.wuhannature.com }\end{array}$} & Bacillus subtilis $\left(2 \times 10^{10} \mathrm{CFU} / \mathrm{g}\right)$. \\
\hline Biozyme & \multicolumn{2}{|c|}{$\begin{array}{l}\text { Bio-Pharmachemie Joint-Venture Company, Ho Chi Minh, Vietnam } \\
\text { http://www.biopharmachemie.com }\end{array}$} & Bacillus subtilis and Saccaromyces cerevisiae. \\
\hline $\begin{array}{l}\text { Fubon Bacillus } \\
\text { subtilis }\end{array}$ & \multicolumn{2}{|c|}{ Angel Yeast Co., Ltd. Hubei, China http://www.angelyeast.com } & Bacillus subtilis ( $\geq 20$ billion CFU/g). \\
\hline Bioron & \multicolumn{2}{|c|}{$\begin{array}{l}\text { American Pharma International, India http://www. } \\
\text { americanpharmainternational.com }\end{array}$} & $\begin{array}{l}\text { Each kg contains: Bacillus subtilis }\left(4.5 \times 10^{8} \mathrm{CFU}\right), \text { B. licheniformis, } B \text {. } \\
\text { megaterium, Lactobacillus lactis, L. helveticus, Nitrosomonas sp. Nitrobacter sp. } \\
\text { Saccharomyces cerevisiae and Aspergillus oryzae. }\end{array}$ \\
\hline Lactomin & \multicolumn{2}{|c|}{$\begin{array}{l}\text { American Pharma International, India http://www. } \\
\text { americanpharmainternational.com }\end{array}$} & $\begin{array}{l}\text { Each kg contains: Bacillus subtilis ( } 45,000 \text { million CFU), B. licheniformis, } \\
\text { Lactobacillus acidophilus, L. sporogenes and Saccharomyces cerevisiae. }\end{array}$ \\
\hline \multicolumn{4}{|c|}{ BACILLUS PROBIOTIC FOR VETERINARY USE } \\
\hline Brand & Animal & Manufacturer & Comments \\
\hline BioGrow $^{\circledR}$ & $\begin{array}{l}\text { Poultry, calves and } \\
\text { swine }\end{array}$ & $\begin{array}{l}\text { Provita Eurotech Ltd., Omagh, Northern } \\
\text { Ireland, UK http://www.provita.co.uk }\end{array}$ & $\begin{array}{l}\text { Listed as containing spores of } B \text {. licheniformis }\left(1.6 \times 10^{9} \mathrm{CFU} / \mathrm{g}\right) \text { and } B \text {. subtilis } \\
\left(1.6 \times 10^{9} \mathrm{CFU} / \mathrm{g}\right)\end{array}$ \\
\hline BioPlus $^{\circledR}$ 2B & $\begin{array}{l}\text { Piglets, chickens, } \\
\text { turkeys for fattening }\end{array}$ & $\begin{array}{l}\text { Christian Hansen Hoersholm, Denmark http:// } \\
\text { www.chr-hansen.com }\end{array}$ & $\begin{array}{l}\text { Mixture (1/1) of } B \text {. licheniformis (DSM 5749) and B. subtilis (DSM 5750) at } \\
1.6 \times 10^{9} \mathrm{CFU} / \mathrm{g} \text { of each bacterium, EU approved }\end{array}$ \\
\hline Biozyme & $\begin{array}{l}\text { Poultry, swine, } \\
\text { shrimp, fish }\end{array}$ & $\begin{array}{l}\text { Bio-Pharmachemie Joint-Venture Company } \\
\text { Ho Chi Minh, Vietnam http://www. } \\
\text { biopharmachemie.com }\end{array}$ & Formulation: B. subtilis and Saccharomyces cerevisiae. \\
\hline Proflora & Poultry & $\begin{array}{l}\text { Zoetis, New Jersey, USA http://www.zoetisus. } \\
\text { com }\end{array}$ & $\begin{array}{l}\text { Proflora is a unique combination product with a Live DFM B. subtilis strain QST } \\
713 \text { plus Beta } \text { Mos }^{\circledR} \text {, a yeast-extract prebiotic. }\end{array}$ \\
\hline Vime-Baciflor & Pigs, poultry & $\begin{array}{l}\text { Vemedin Corporation, Can Tho, Vietnam } \\
\text { http://www.vemedim.vn }\end{array}$ & Bacillus subtilis. \\
\hline
\end{tabular}

Table 1: Bacillus subtilis commercial products from humans and animals.

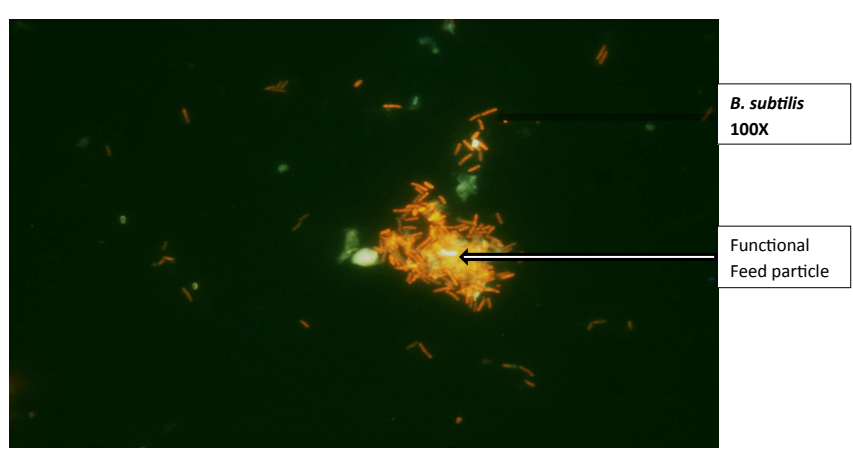

Figure 3: Functional Feed particle formulated with soybean meal, complex carbohydrates, vegetable oil and Bacillus subtilis multifunctional probiotic strain [20]

in wild fisheries, unsustainable aquaculture development may aggravate the problems and create new ones, damaging our important and already-stressed coastal areas [53]. In order to solve these aquaculture restrictions, the development of Functional Feeds using alternativeeconomical vegetable protein, carbohydrates, lipids and "Bacillus subtilis spore producing multifunctional probiotic bacterium" are recommended, to increase aquaculture profitability and environmental and ecological sustainability [16-19,24].

\section{Importance of Functional Feed Development in Aquaculture}

The rapid development of aquaculture from last years has increased feed ingredients demand and its prices, for this reason feeding represent $40-60 \%$ of the total production costs in shrimp/fish farming. In this sense, aquaculture industry development has become a great challenge for future generations; not only for feeding expenses but also from availability of fishmeal and oil ingredients. Reduced inclusion of fishmeal and oil in formulations is a tendency for almost a decade. It is estimated that these ingredients will be minimal or null in diets by the year 2020 [50]. Consequently, alternative feed formulation ingredients development is urgent and they must meet the animal nutritional requirements, be less expensive and sustainable with the environment [17,18,35,51,52,54-57]. Partial or complete fishmeal and oil substitution by alternative-economic vegetable protein, carbohydrates and lipids has been the goal to the field for more than 10 years, without satisfactory results due toxic effects and anti-nutritional nature of some vegetable molecules [58-63]. However, feeds evolution with inclusion of vegetable ingredients inducing; growth, health, environmental and economic benefits beyond traditional feeds, is a great opportunity to assure the future of a profitable and sustainable aquaculture [16-19,24]. Nevertheless, proteases, carbohydrases and lipases limited expression in shrimp/fish is the major obstacle to digestion and assimilation of vegetable ingredients, regulating its high level inclusion in feed 
formulations [58-63]. Thus, the utilization of specifically selected "Bacillus subtilis spore producing multifunctional probiotic bacterium" has emerged as a solution with huge applications in the aquaculture feeding industry (Figures 1 and 2). In this sense, excellent results have been obtained in Litopenaeus vannamei, Oreochrmis niloticus and Atractoscion nobilis; increasing digestion-assimilation of vegetable ingredients, improving Food Conversion Ratio (FCR) and inducing optimal growth on cultivated animals, when a B. subtilis probiotic strain have been added to feeds. Additionally, inhibition of pathogens proliferation and increased health status of animals was also improved. Finally, bioremediation of pond contaminated water was also achieved efficiently by $B$. subtilis probiotic bacteria used [16-19,24]. These results open great opportunities to new Functional Feeds production for shrimp and fish aquaculture (Figure 3).

Complex carbohydrates degradation, proteases inhibitors inactivation and lipids assimilation, were not a problem to animals when "Bacillus subtilis spore producing multifunctional probiotic bacterium" was added to vegetable based-feed formulations [16-19,24].

\section{Conclusion}

The world market for probiotics supplements has been growing for the last 50 years; today most dairy human products contain probiotic bacteria. Lactobacillus and Bifidobacterium are the most used genera principally for the exclusion of pathogens in humans and animals. However, species of these genera do not present multifunctional probiotic capacities as $B$. subtilis does [15-19,24]. In this sense, animal feed preparation processes usually require high temperatures and only spore producer bacteria are optimal to support these conditions. Other Bacillus than B. subtilis can also be used for feed preparation, however B. subtilis is one of the few recognized as safe by the FDA. $B$. subtilis enzymes support extreme environmental conditions increasing digestive human and animal capabilities, to assimilate ingredients from animal and plant origin [16-19,24]. The capacity of $B$. subtilis to grow aerobically and anaerobically allows this bacterium to survive and growth adequately inside and outside humans and animals, and in aquaculture water systems. All these properties give B. subtilis the potential capacity to become one of the "most perfect multifunctional probiotic bacteria" to formulate Functional Feeds for aquaculture. However, B. subtilis probiotic properties are strain-specific meaning bioprospection and selection methods needs to be well designed.

\section{Acknowledgement}

The authors wish to thanks Rosalia Contreras and Leonel Ochoa for technical assistance. This work was done with support of CONACYT project CB-131115.

\section{References}

1. Sonnenschein AL, Losick R, Hoch JA (1993) Bacillus subtilis and Others GramPositive Bacteria: Biochemistry, Physiology and Molecular Genetics. American Society for Microbiology, Washington, DC.

2. Garbeva P, van Veen JA, van Elsas JD (2003) Predominant Bacillus spp. in agricultural soil under different management regimes detected via PCR-DGGE. Microb Ecol 45: 302-316.

3. Nicholson WL (2004) Ubiquity, longevity, and ecological roles of Bacillus spores. In Bacterial Spore Formers: Probiotics and Emerging Applications, Ricca E, Henriques AO, Cutting SM (eds). Norflok, Horison Bioscience, pp $1-15$.

4. Ivanova EP, Vysotskii MV, Svetashev VI, Nedashkovskaya OI, Gorshkova NM, et al. (1999) Characterization of Bacillus strains of marine origin. Int Microbiol 2: $267-271$.

5. Andersson AM, Weiss N, Rainey F, Salkinoja-Salonen MS (1999) Dust-borne bacteria in animal sheds, schools and children's day care centres. J Appl Microbiol 86: 622-634.
6. Kunst F, Ogasawara N, Moszer I, Albertini AM, Alloni G, et al. (1997) The complete genome sequence of the gram-positive bacterium Bacillus subtilis. Nature 390: 249-256.

7. Harwood CR, Cutting SM (1990) Molecular Biological Methods for Bacillus Wiley, Chichester, England, pp. 1-581.

8. Olmos J, Bolaños V, Causey S, Ferrari E, Bollvar F, et al. (1996) A functional $\mathrm{SpoOA}$ is required for maximal aprE expression in Bacillus subtilis. FEBS Lett 381: 29-31.

9. Olmos J, de Anda R, Ferrari E, Bolívar F, Valle F (1997) Effects of the sinR and degU32 (Hy) mutations on the regulation of the aprE gene in Bacillus subtilis. Mol Gen Genet 253: 562-567.

10. Bérdy J (2005) Bioactive microbial metabolites. J Antibiot (Tokyo) 58: 1-26.

11. Stein $T$ (2005) Bacillus subtilis antibiotics: structures, syntheses and specific functions. Mol Microbiol 56: 845-857.

12. Ferrari E, Jarnagin AS, Schmidt BF (1993) Commercial production of extracellular enzymes. In: Sonenshein AL, Hoch JA, Losick R (Eds.), Bacillus subtilis and Other Gram-Positive Bacteria. American Society for Microbiology, Washington, DC, pp. 917-937.

13. Olmos-Soto J, Contreras-Flores R (2003) Genetic system constructed to overproduce and secrete proinsulin in Bacillus subtilis. Appl Microbiol Biotechnol 62: 369-373.

14. Westers L, Westers H, Quax WJ (2004) Bacillus subtilis as cell factory for pharmaceutical proteins: a biotechnological approach to optimize the host organism. Biochim Biophys Acta 1694: 299-310.

15. Valdez A, Yepiz-Plascencia G, Ricca E, Olmos J (2014) First Litopenaeus vannamei WSSV $100 \%$ oral vaccination protection using CotC::Vp26 fusion protein displayed on Bacillus subtilis spores surface. J Appl Microbiol 117: 347357.

16. Ochoa SJL, U.S. Patent 2012/0128827 A1, May 24, 2012

17. Ochoa-Solano J, Olmos-Soto J (2006) The functional property of Bacillus for shrimp feeds. Food Microbiol 23: 519-525.

18. Arellano CF, Olmos SJ (2002) Thermostable a-1,4- and a-1-6-glucosidase enzymes from Bacillus spp. isolated from a marine environment. World $J$ Microb Biot 18: 791-795

19. Olmos J, Ochoa L, Paniagua-Michel J, Contreras R (2011) Functional feed assessment on Litopenaeus vannamei using $100 \%$ fish meal replacement by soybean meal, high levels of complex carbohydrates and Bacillus probiotic strains. Mar Drugs 9: 1119-1132.

20. Rengpipat S, Phianphak W, Piyatiratitivorakul S, Menasvetac P (1998) Effects of a probiotic bacterium on black tiger shrimp Penaeus monodon survival and growth. Aquaculture 167: 301-313.

21. Guo JJ, Liu KF, Cheng SH, Chang Cl, Lay JJ, et al. (2009) Selection of probiotic bacteria for use in shrimp larviculture. Aquac Res 40: 609-618.

22. Paniagua-Michel J, Franco-Rivera A, Cantera JJL, Stein LY (2005) Activity of nitrifying biofilms constructed on low-density polyester enhances bioremediation of a coastal wastewater effluent. World J Microb Biot 21: 1371-1377.

23. Sorokulova I (2013) Modern status and perspectives of Bacillus bacteria as probiotics. J Prob Health 1: 1-5.

24. Olmos SJ, Paniagua-Michel J, Lopez L, Ochoa S L (2014) Functional feeds in aquaculture. S.-K. Kim (Ed.), Handbook of Marine Biotechnology. NY: Springer, ISBN: 978-3-642-53970-1, $1800 \mathrm{pp}$

25. Vreeland RH, Rosenzweig WD, Powers DW (2000) Isolation of a 250 millionyear-old halotolerant bacterium from a primary salt crystal. Nature 407: 897-900.

26. Fajardo-Cavazos P, Nicholson WL (2006) Bacillus endospores isolated from granite: close molecular relationships to globally distributed Bacillus spp. from endolithic and extreme environments. Appl Environ Microbiol 72: 2856-2863.

27. Cutting SM (2011) Bacillus probiotics. Food Microbiol 28: 214-220.

28. Bassler BL, Wright M, Showalter RE, Silverman MR (1993) Intercellula signalling in Vibrio harveyi: sequence and function of genes regulating expression of luminescence. Mol Microbiol 9: 773-786.

29. Bassler BL, Greenberg EP, Stevens AM (1997) Cross-species induction of luminescence in the quorum-sensing bacterium Vibrio harveyi. J Bacteriol 179 : 4043-4045. 
30. Nikaido H (2009) Multidrug Resistance in Bacteria. Annu Rev Biochem 78: 119146

31. Reid G, Hass J, Sebulsdy MT, McCormick JD (2003) Potential use of probiotics in clinical practice. Clin Microbiol Rev 16: 658-672.

32. FAO/WHO (2006) Probiotic in foods: Health and nutritional properties and guidelines for evaluation. In FAO food and nutrition; 2005 pp 85, ISBN 92-5105513-0.

33. Gatesoupe FJ (1999) The use of probiotics in aquaculture. Aquaculture 180 147-165.

34. Naidu KSB, Adam JK, Govender P (2012) The use of probiotics and safety concerns: A review. Afr J Microbiol Res 6: 6871-6877.

35. Rurangwa E, Laranja JL, Van Houdt R, Delaedt Y, Geraylou Z, et al. (2009) Selected nondigestible carbohydrates and prebiotics support the growth of probiotic fish bacteria mono-cultures in vitro. J Appl Microbiol 106: 932-940.

36. Lara-Flores M (2011) The use of probiotic in aquaculture: an overview. Int Res J Microbiol 2: 471-478.

37. Shen WY, Fu LL, Li WF, Zhu YR (2010) Effect of dietary supplementation with Bacillus subtilis on the growth, performance, immune response and antioxidant activities of the shrimp. Aquac Res 41: 1691-1698.

38. Caruso A, Flamminio G, Folghera S, Peroni L, Foresti I, et al. (1993) Expression of activation markers on peripheral-blood lymphocytes following oral administration of Bacillus subtilis spores. Int $\mathrm{J}$ Immunopharmacol 15: 8792.

39. Huang Q, Xu X, Mao YL, Huang Y, Rajput IR, et al. (2013) Effects of Bacillus subtilis $B 10$ spores on viability and biological functions of murine macrophages. Anim Sci J 84: 247-252.

40. Balcázar JL, Rojas-Luna T, Cunningham DP (2007) Effect of the addition of four potential probiotic strains on the survival of pacific white shrimp (Litopenaeus vannamei) following immersion challenge with Vibrio parahaemolyticus. J Invertebr Pathol 96: 147-150.

41. Verschuere L, Rombaut G, Sorgeloos P, Verstraete W (2000) Probiotic bacteria as biological control agents in aquaculture. Microbiol Mol Biol Rev 64: 655-671.

42. Merrifield DL, Bradley G, Baker RTM, Davies SJ (2010) Probiotic applications for rainbow trout (Oncorhynchus mykiss Walbaum) II. Effects on growth performance, feed utilization, intestinal microbiota and related health criteria postantibiotic treatment. Aquac Nut 16; 496-503.

43. Sorokulova IB, Beliavskaia VA, Masycheva VA, Smirnov VV (1997) Recombinant probiotics: problems and prospects of their use for medicine and veterinary practice. Vestn Ross Akad Med Nauk 46-49.

44. Liu L, Liu Y, Shin HD, Chen RR, Wang NS, et al. (2013) Developing Bacillus spp. as a cell factory for production of microbial enzymes and industrially important biochemicals in the context of systems and synthetic biology. App Microbiol Biotechnol 97: 6113-6127.

45. Terpe K (2006) Overview of bacterial expression systems for heterologous protein production: from molecular and biochemical fundamentals to commercial systems. Appl Microbiol Biotechnol 72: 211-222.

46. Witteveldt J, Vlak JM, van Hulten MC (2006) Increased tolerance of Litopenaeus vannamei to white spot syndrome virus (WSSV) infection after oral application of the viral envelope protein VP28. Dis Aquat Organ 70: 167-170.

47. Jha RK, Xu ZR, Shen J, Bai SJ, Sun JY, et al. (2006) The efficacy of recombinan vaccines against white spot syndrome virus in Procambarus clarkii. Immunol Lett 105: 68-76.

48. Cutting SM, Hong HA, Baccigalupi L, Ricca E (2009) Oral vaccine delivery by recombinant spore probiotics. Int Rev Immunol 28: 487-505.

49. FAO (2012) The state of world fisheries and aquaculture 2011. Food and Agriculture Organization of United Nations. FAO, Viale delle Terme di Caracalla, 00153 Rome, Italy.
50. Tacon AGJ, Metian M (2008) Global overview on the use of fish meal and fish oil in industrially compounded aquafeeds: Trends and future prospects. Aquaculture 285: 146-158.

51. Li X, Li J, Wang Y, Fu L, Fu Y, et al. (2011) Aquaculture Industry in China: Current State, Challenges, and Outlook. Rev Fish Sci 19: 187-200.

52. Zhanga S, Li G, Wua H, Liub X, Yaoa Y, et al. (2011) An integrated recirculating aquaculture system (RAS) for land-based fish farming: The effects on water quality and fish production. Aquacult Eng 45: 93-102.

53. Anh P, Kroeze C, Bush S, Mol A (2010) Water pollution by intensive brackish shrimp farming in south-east Vietnam: Causes and options for control. Agr Water Manage 97: 872-882.

54. Bautista-Teruel MN, Eusebio P, Welsh T ( 2003) Utilization of feed pea, Pisum sativum, meal as a protein source in practical diets for juvenile tiger shrimp, Penaeus monodon. Aquaculture 225: 121-131.

55. Bomba A, Nemcová R, Gancarcíková S, Herich R, Guba P, et al. (2002) Improvement of the probiotic effect of micro-organisms by their combination with maltodextrins, fructo-oligosaccharides and polyunsaturated fattyacids. $\mathrm{Br}$ J Nutr 88: 95-99.

56. Boyd CE, Tucker CS (1998) Pond Aquaculture Water Quality Management Kluwer Academic Publishers, USA.

57. Chen JC, Liu PC, Lei SC (1990) Toxicity of ammonia and nitrite to Penaeus monodon adolescents. Aquaculture 89: 127-137.

58. Colt JE, Armstrong DA (1981) Nitrogen toxicity to crustaceans, fish and mollusks. Proceedings of the bio-engineering symposium for fish culture. Fish culture section of the American fisheries society (FCS Publ. 1): 34-47.

59. Rosas C, Cuzon G, Taboada G (2001) Effect of dietary protein and energy levels on growth, oxygen consumption, haemolymph and digestive gland carbohydrates, nitrogen excretion and osmotic pressure of Litopenaeus vannamei (Boone) and L. setiferus (Linne) juveniles (Crustacea, Decapoda; Penaeidae). Aquac Res 32: 531-547.

60. Daranee S, Davis DA (2011) Pond production of Pacific white shrimp (Litopenaeus vannamei) fed high levels of soybean meal in various combinations. Aquaculture 319: 141-149.

61. Enes P, Panserat S, Kaushik S, Oliva-Telesa A (2008) Growth performance and metabolic utilization of diets with native and waxy maize starch by gilthead sea bream (Sparus aurata) juveniles. Aquaculture 274: 101-108.

62. German DP, Horn MH, Gawlicka A (2004) Digestive enzyme activities in herbivorous and carnivorous prickleback fishes (Teleostei: Stichaeidae) ontogenetic, dietary, and phylogenetic effects. Physiol Biochem Zool 77: 789804

63. Hemre GI, Shiau SY, Deng FD, Storebakken T, Hung SSO (2002) Utilization of hydrolyzed potato starch by juvenile Atlantic salmon when using a restricted feeding regime. Aquac Res 31: 207-212. 